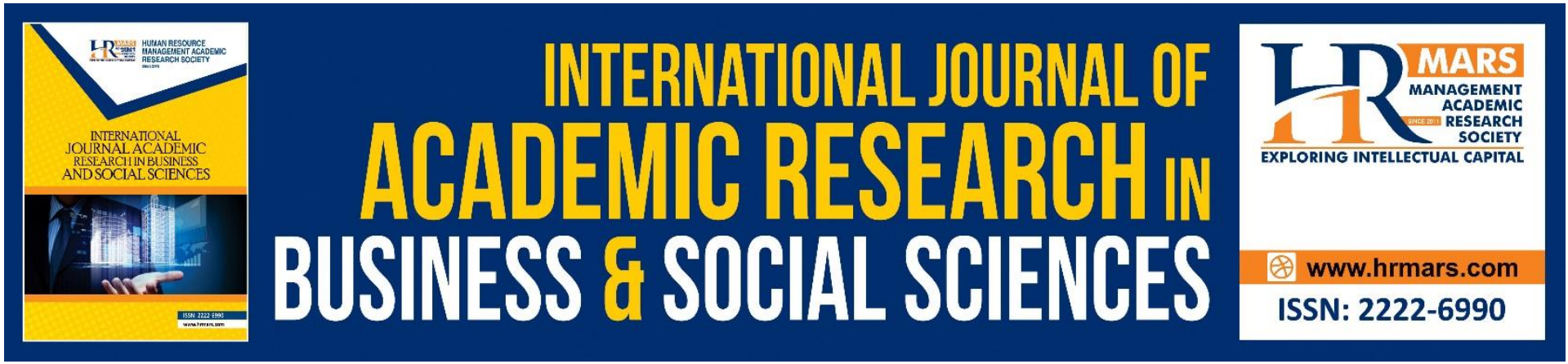

\title{
A Phenomenological Study on International Student Withdrawals from Malaysian Higher Education Institutions
}

\section{Norizan Sulong \& Nooraini Othman}

To Link this Article: http://dx.doi.org/10.6007/IJARBSS/v10-i12/8323

DOI:10.6007/IJARBSS/v10-i12/8323

Received: 11 October 2020, Revised: 13 November 2020, Accepted: 29 November 2020

Published Online: 16 December 2020

In-Text Citation: (Sulong \& Othman, 2020)

To Cite this Article: Sulong, N., \& Othman, N. (2020). A Phenomenological Study on International Student Withdrawals from Malaysian Higher Education Institutions. International Journal of Academic Research in Business and Social Sciences, 10(12), 363-376.

\section{Copyright: (c) 2020 The Author(s)}

Published by Human Resource Management Academic Research Society (www.hrmars.com)

This article is published under the Creative Commons Attribution (CC BY 4.0) license. Anyone may reproduce, distribute, translate and create derivative works of this article (for both commercial and non-commercial purposes), subject to full attribution to the original publication and authors. The full terms of this license may be seen at: http://creativecommons.org/licences/by/4.0/legalcode

$$
\text { Vol. 10, No. 12, 2020, Pg. } 363 \text { - } 376
$$

Full Terms \& Conditions of access and use can be found at http://hrmars.com/index.php/pages/detail/publication-ethics 


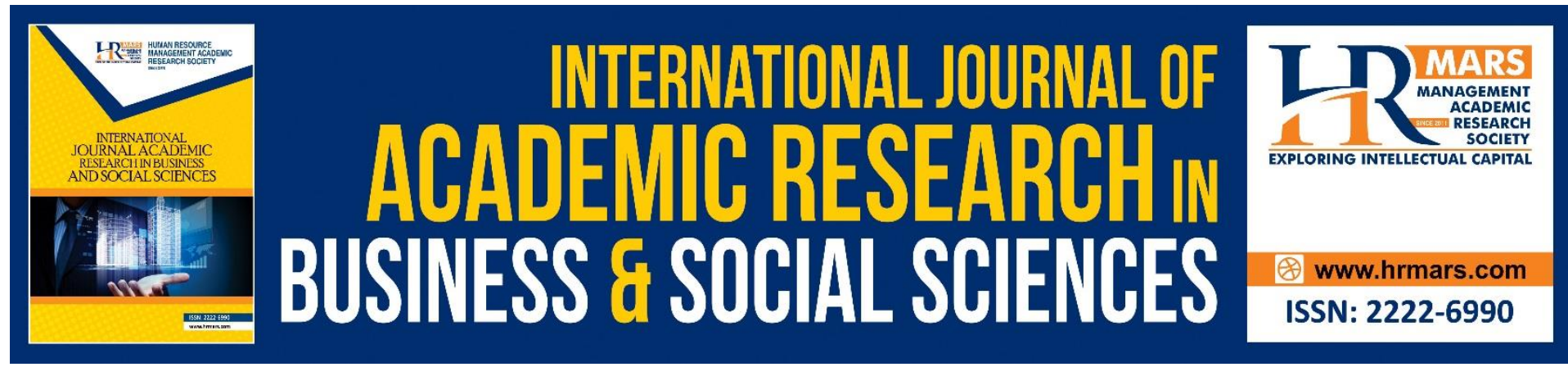

\title{
A Phenomenological Study on International Student Withdrawals from Malaysian Higher Education Institutions
}

\author{
Norizan Sulong \& Nooraini Othman \\ Perdana Centre of Science, Technology \& Innovation Policy, Universiti Teknologi Malaysia \\ Email: snorizan4@live.utm.my, p-noraini@utm.my
}

\begin{abstract}
Over the past two decades, the internationalisation of higher education in Malaysia has become a national priority as one of the key economic drivers for foreign exchange. The internationalisation strategy has concentrated on international student enrolment number, ignoring the student withdrawal or dropout issue in the system. While the focus of most dropout studies in higher education has always been on the traditional campus setting that serve local students, most studies on international student withdrawal are from information system and computer field, utilizing data set approach and predicting the risk of dropping out. Thus, this study is an attempt to investigate the phenomenon of international student withdrawals from higher institutions in Malaysia. Twenty-four interviews were conducted with former international students who dropped out of Malaysia higher institutions and moved to North Cyprus to continue their educational pursuit. The investigation focuses on the descriptions of the lived experiences of participants using a phenomenological approach.
\end{abstract}

\section{Introduction}

The presence of international students in many higher education institutions in Malaysia has become a significant student population. Not only do they provide the institutions with economic benefits, but they also internationalize the campus environment, which is particularly beneficial for local students in preparing them to become global graduates, while at the same time developing the country's first-class human capital. There are two issues to be raised in this article; firstly, the pattern of international student enrolment in higher education institutions in Malaysia and, secondly, the phenomenon of international student early withdrawal from higher education institutions and how it relates to the former.

First, since the reformation of higher education sector in the past two decades, the enrolment pattern of international students in Malaysian higher educational institutions has been steadily rising until recently. Latest statistics show the pattern was reversing with a sharp decline of around 40,000 or 30 per cent in enrolment from 136,293 in 2017 to just 93,569 students in 2019, indicating a potential failure of the higher education sector in achieving the national goal of 200,000 international student enrolment by 2020 (MoHE, 2015). Figure 1 
illustrates the pattern of international students enrolled in various Malaysian higher institutions from 2002 to 2019.

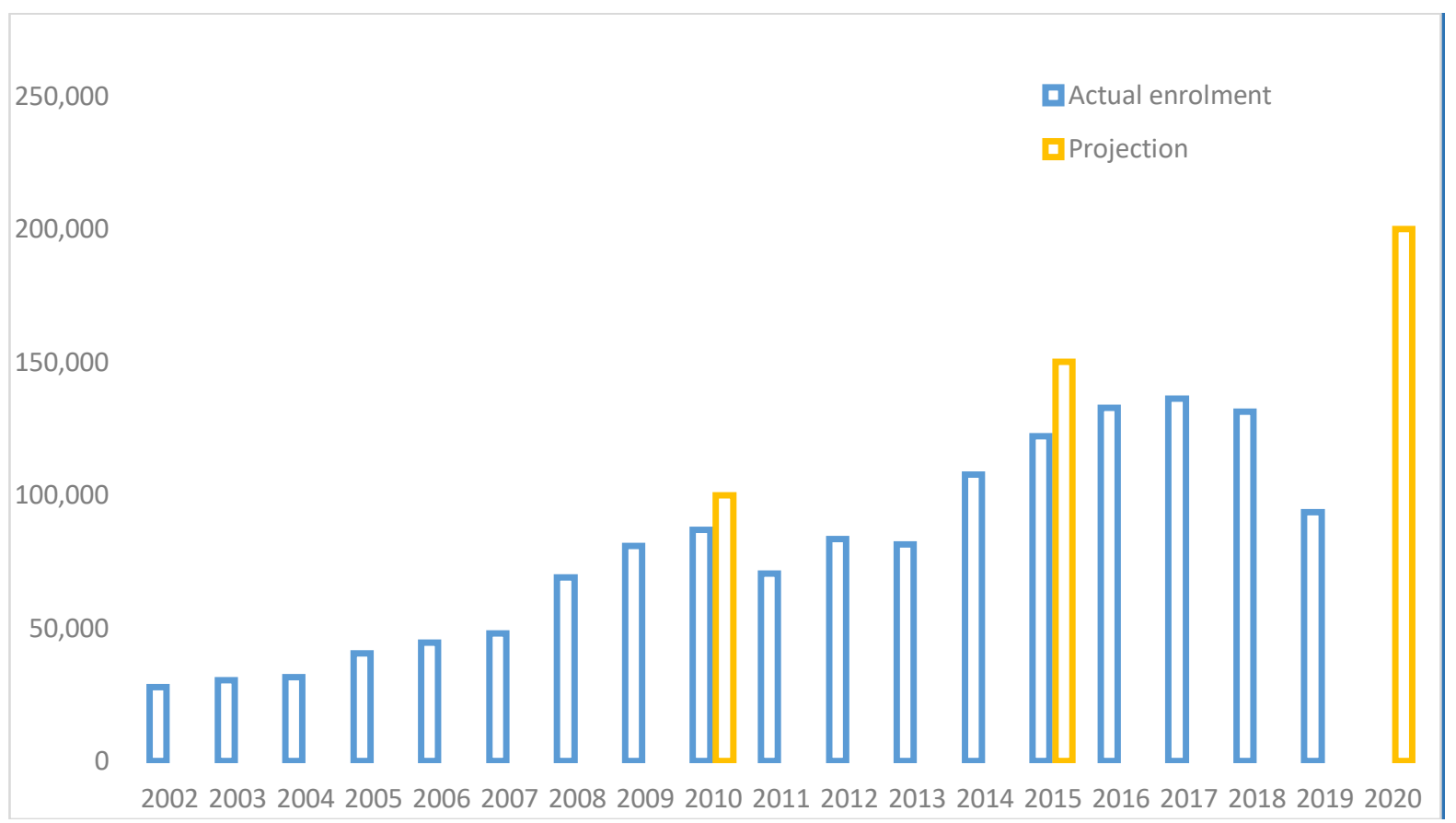

Figure 1: International student enrolment from 2002 to 2019 (Source: MOHE 2020)

Despite various efforts in transforming the country as one of internationally recognized education hubs excellence in this region, the unfavorable enrolment pattern as illustrated in Figure 1 shows Malaysia may need to recalibrate its strategy for oncoming years. A continuous decline in international student enrolment may pose significant risks for an institution sustainability as well as Malaysia reputation as a higher education provider in the region. Thus, the aspiration of becoming an education hub is now questionable as some hinted earlier that they might be more of a fad likely to fade than a trend likely to continue (Dessoff, 2012). Secondly, although there was a promising increase in student numbers, some international students, for reasons yet unknown, had withdrawn without completing their studies from Malaysian higher institutions and continued their higher education pursuit in other countries. They did not transfer institutions within Malaysia, but completely dropped out from the system and moved elsewhere. In addition, while the literature is abundant with various studies on international student-related issues, there are limited works available on the issue of international student withdrawal, commonly described as drop-out. The lack of study on international student drop-out, especially with the in-depth qualitative approach is glaringly lacking. Thus, this study tries to explore and understand the phenomenon of international student withdrawals from Malaysian higher institutions and its possible link to the declining pattern of international student enrolment in Malaysia higher institutions. The research site location is a small island state, the Turkish Republic of Northern Cyprus (TRNC) or simply known as North Cyprus, located in the Mediterranean Sea, and is still not recognized by the United Nations. The objectives of the study are two-fold:

- to examine the lived experiences of the former international students who dropped out from Malaysian higher institution, 
- $\quad$ based on the descriptions of their lived-experiences, to identify influential factors which led to their early withdrawals.

The phenomenological study was to gain systematic descriptions of the lived experience of former international undergraduate students who have left without completing their studies but continued in other countries. The specific question that guided this study is: How did the lived experiences of international students influence their early withdrawal from Malaysia higher institutions? Some terms used in this paper need clear definition before further discussion.

\section{Withdrawal (drop out)}

In the context of this study, withdrawal refers to a situation where a student removes themselves, either voluntarily or involuntarily, from any higher education institution for the subsequent semester and left Malaysia but continued their higher education pursuit elsewhere. The term is commonly used interchangeably with departure, attrition, retention and drop out in the education literature. Tinto (1988) suggested that scholars and practitioners should use the word departure rather than drop out to characterize students who leave their initial college or university of enrolment.

\section{International Student}

The term 'international student' has always been loosely used in literature as a student holding foreign nationality who is pursuing post-secondary education outside of their home country. Abdullah et al. highlighted the variation in the use of the term in various literature( Abdullah, Abd Aziz, \& Ibrahim, 2014). This may be due to the nature of the students themselves who undertake different types of mobility and adds to the complexity in interpreting the terms used. Common terms used in the literature are international student, overseas student, foreign student, non-local student, Asian student, and non-English speaking student. For this research study, international student is defined as a non-citizen who came to Malaysia on temporary student visa and enrolled in any higher education institution or centre, for higher education purposes. In this paper, wherever the term 'student' is used, it is specifically referred to international students, unless stated otherwise.

\section{Review of Literature}

The increasing number of student mobility in the past decades has changed the landscape of higher education across the globe. It is no longer a free service of knowledge transfer, but rather it has become a tradable commodity for foreign exchange. As such, there has been increasing global competition for international students, not just among Anglo-Saxon countries, continental Europe, but also from emerging economies in Asia, Middle East, South Africa and Central Asia (de Wit, 2008). Such change has also given rise to countries aspiring to become regional education hubs, including Malaysia.

\section{Higher Education in Malaysia}

A policy document, National Higher Education Strategic Plan 2020 (NHESP 2020), Malaysia stated its aspiration to be educational hub excellence in the Asian region and targeted for 200,000 international students enrolment in its various education institutions by the year 2020 (MoHE, 2007). Through its Ministry of Higher Education (MOHE), Malaysia introduced various incentives and allocated a significant portion of the national annual budget to attract international students to its shores. MOHE is committed to ensure that international 
perception about the country's higher education quality is to be maintained at the highest level (MoHE, 2018). As such, it monitors higher institutions and takes stringent action against institutions that fail to adhere to regulations that the ministry sets. Monetarily, Malaysia has also sustained high levels of investment in education, particularly on infrastructure over the past 63 years since its independence. For example, from 2004 to 2014, it increased its total expenditure on higher education by $13 \%$ per annum, from RM4.3 billion to RM15.1 billion. This increase was driven by a $6 \%$ increase in student enrolment and a $7 \%$ rise in per-student costs (MoHE, 2015). A similar commitment was shown in its 2018 annual budget in which allocation for higher education sector alone was increased by $13.15 \%$ from the previous year to RM13.9 billion and made aggressive efforts in redesigning higher education sector to place itself as global education provider (MoHE, 2018). Malaysia seemed to be on the right track in positioning itself as an education hub, and logically efforts should continue in strengthening its standing. The Department of Higher Education, among others, is tasked to ensure that higher education in Malaysia is aligned with the goals of national policies and international trends, and therefore is to formulate, monitor and evaluate policies related to higher education in Malaysia, including but not limited to the establishment of higher education institutions, governance, quality assurance, student development, research, and institutional excellence (MoHE, 2017).

\section{Student Withdrawal}

In reviewing the literature, there is a long history of research in English-speaking countries onto the phenomenon of student withdrawals in English-speaking countries, from primary education to tertiary levels. Adams and Becker (1990) argued that withdrawals are problematic not only because they are costly, but more importantly because they indicate that a breakdown in the system has occurred because the student is willing to drop a course with no, or little, tuition refund. Meanwhile, Aina, Casalone, Baici, \& Pastore (2018) claimed that university dropout and delayed graduation are the results of a sequential process made under gradually decreasing levels of uncertainty on education costs and future returns. They demonstrated that the increase in dropouts and delayed graduations dating back to the $90 \mathrm{~s}$ was caused not only by a decrease in financial and human resources per student, but also by an upturn in enrollment in universities with poorer resources.

Most of the research done in the past forty years has been much influenced by Spady's (1970) and Tinto's $(1975,1993)$ integration models of student retention. The integration models suggest the need for a match between the institutional environment and student commitment in order for higher student integration into the academic and social domains of college life and thus greater probability of persistence (Tinto, 1975). Tinto further added that for students with even high levels of academic involvement and its consequent learning may not be enough to offset the effect of social non-integration. Students who do not achieve highly in academic but are socially well integrated may stay because of the friendships they have developed (Tinto, 1997). He also reminded that the absence of any academic involvement typically leads to academic failure and thus forced withdrawal. Prominent works which were based on Tinto's work include Astin's student involvement theory (1984), conceptual model for non-traditional students by Bean and Metzner (1985) and psychological model on student persistence introduced by Ethington (1990). All empirical analyses show that there is rarely only one reason for dropping out and there is also a general consensus that student drop-out is not as a result of spontaneous, short-term decisions, but of a complex progression, which normally involved prolonged decision-making process in which 
the different influencing factors accumulate that makes leaving the higher education institution seem inevitable (Ashour, 2019; Burke, 2019; Kehm, Larsen, \& Sommersel, 2019; Kercher, 2018; Rose \& Said, 2018; Owens, 2009). As such, examination of the student experience started from the point of arrival in Malaysia to the time that the students decided to withdraw and leave which includes four main experiences at arrival and orientation, learning, living, and support provisions. This is also consistent with the approach used by the i-graduate's International Student Barometer index (ISB) which tracks and compares decisionmaking, expectations, perceptions, and intentions of the students from application to graduation (Perring, 2014). Understanding the decision-making process in the selection and expectation of the institution is also crucial in understanding the international student withdrawal phenomenon.

\section{Choosing a University}

In choosing an institution abroad, a student has two layers of decision-making process; the country and the institution itself. There are some pull and push factors that are influential in a student decision to go abroad. While the economic and social forces within the home country serve to 'push' students to study abroad the choice, the decision as to which host country they will select is dependent on a variety of 'pull' factors (Mazzarol \& Soutar, 2002). In a recent published study, Perez-Encinas \& Rodriguez-Pomeda, (2018) found that the reputation of the higher institution is perceived to be influential in student's decision concerning their experience abroad. The study also found that the academics, costs, culture, friendliness, and information are the dominant issues in the students' perceptions. This is consistent with the pull and push factors as proposed by Mazzarol and Soutar (2002). Ergin, de Wit, \& Leask, (2019) discussed the emerging phenomenon of forced internationalization in some countries with high number of forced migrants due to forces beyond their control such as countries in conflict like Syria. There are high numbers of students from Syria who had to continue their higher education in neighboring country like Turkey.

Various studies have observed that most student withdrawals occur during the critical first year after their arrival (Cabrera, Tomás, Alvarez, \& González, 2006; Huo et al., 2020; Lassibille \& Gómez, 2008; Mitchell, 1942; Willcoxson, Cotter, \& Joy, 2011). Most of the studies claimed that individual characteristics of the students, such as low academic performance or preparedness, age, financial problems, family related matters, and low commitment to studies are influential factors in students' withdrawals. While most studies focus on the individual characteristic of the students in explaining student withdrawal, there are also several studies investigating the institutional characteristics in influencing such behavior. For example, a study discovered that organizational aspect of university courses have significant impact on student withdrawals (Gitto, Minervini, \& Monaco, 2016). The study also found that reorganizing remote branches might prevent student withdrawals.

\section{Experiences of Arrival and Orientation}

Arriving in a new country with different environments than a student was used to can be daunting experience but with the provision of support service such as airport pick-up and orientation program can offer new international students with a sense of support and acceptance (Australian Government, 2015). Furthermore, commencing with a positive experience reduces the fear of the unknown allowing the new students to feel safe and able to navigate the remaining period of their study. The ISB index on student's satisfaction 
indicates that students are generally more satisfied with institutions which provide effective orientation program.

\section{Experience of Learning}

While Lassibille \& Gomez, (2008) found the timing of departures varies across programs, and significant variations do exist in withdrawal rates according to time spent in the program, a study by DeMonbrun, Brown, \& Teasley, (2019) revealed significant relationships between student success and co-enrollment patterns, including: the disciplinary alignment of the course with a student's major, the student's co-enrollment in other difficult courses and experiencing below average academic performance in a co-enrolled course. One of the ways to prevent student withdrawal, Outhred \& Chester, (2013) suggested for an inclusive approach of an internationalised curricula by providing internationalized peer mentoring classroom initiative in the students' first year to expose them to a challenging internationalized curriculum as well as to enhance learning climate experience.

\section{Experience of Living (adjustment)}

Various researches described that the lack of a sense of belonging, feeling cut off from family, friends, or school, students withdrawal is the inability to connect meaningfully with other people, and is particularly common among students of all levels (A. Abdullah, 2013; Barney, 2016; Cummings, 2014; Geisinger \& Raman, 2013; Hilaluddin, 2013). Many variables such as changes in family circumstances, lack of social acceptance, academic underachievement, and oppressive or inequitable practices can trigger feelings of isolation and disconnection from family, friends, and the community.

\section{Provision of Student Support Services}

Although there is limited number of studies done on which services are needed and expected from an institutions, the provision of services to international students has been one of the important topics being discussed in the internationalization of higher education (Martirosyan, Bustamante, \& Saxon, 2019; Perez-Encinas \& Rodriguez-Pomeda, 2018). Students with low self-control, the ability to exercise self-restraint or to alter one's own responses to stimuli, are 8 percent more likely to withdraw within the first year of their study compared to those with higher self-control (Stephenson, Heckert, \& Yerger, 2020).

\section{Research on International Student Withdrawal}

Although there is a plethora of research done on the issue of student withdrawals, it is hard to find in-depth investigation on international student withdrawals, neither at schools nor higher institution levels. The studies done so far were focusing on local students or specific group of students in primary, secondary and high school levels, and post-secondary levels which include colleges, vocational and university students. Furthermore, several studies have attempted to build models to evaluate and predict student dropout or at students at risk of dropping out using meta data (Rovira, Puertas, \& Igual, 2017; Sangodiah, Beleya, Muniandy, Heng, \& SPR, 2015; Tarmizi, Mutalib, Hamid, \& Rahman, 2019; Von Hippel \& Hofflinger, 2020). Such studies have mixed local (domestic) and international students with a data mining approach. Only a handful of research done on international student withdrawals or more frequently referred to as drop out which just started recently. To the best knowledge of the researcher and at the time of this paper being prepared, this qualitative study with phenomenological approach is the first thorough investigation on the issue of international 
student withdrawals that has been conducted, from the lens of the former students themselves.

\section{Methodology}

Qualitative research that recounts the experiences of the international students regarding withdrawal and academic failure is limited, even more so an in-depth investigation with qualitative approach. While Creswell (2014) said that the goal of most qualitative research is not to generalize but to gain an in-depth understanding of a topic or phenomenon under investigation, this qualitative study which uses specific approach, a phenomenological in its methodology, focuses on the meaning that individuals make of an experience (Moustakas, 1994). In addition, the study stresses on the commonalities of experience shared by a group of individuals that aims to describe the essence of a particular phenomenon Creswell \& Pot, (2018). As such, the phenomenological approach was chosen as the most appropriate method in the examination of participants' descriptions of lived experience when studying in Malaysian higher institutions. Phenomenological research begins with the assumption that an essence, or invariant structure, exists within each lived experience. Intrinsically, the aim of this study is to discover the invariant structure within the perceptions and experiences of former international students whose lived experiences had influenced their withdrawals from Malaysian higher education scene. The understanding is gained from the perspective of the former students themselves in which their voices can be heard, and to allow their side of stories to be shared and more understood \{Formatting Citation\}.

Although the setting of the study is the Malaysian higher education sector, all semi-structured in-depth interviews were conducted in the participant's new location North Cyprus, except for one who was interviewed before he left Malaysia. North Cyprus became the research site for several reasons. Firstly, several Malaysian private university marketing staff had lamented that international students had moved to the lesser known island (Akiba, 2008). Secondly, a network of student recruiting agents based in the middle east had shared their views about student feedback in Malaysia higher education and decided to send some of the students to the small island state. Finally, today's communication technology offers platforms for international students and their families to exchange information by word-of-mouth at a faster rate.

The study began with consultations with several key persons in Malaysian higher education sector and followed by data collection and analysis, which include in-depth interviews with research participants, field observation and document analysis. The purpose of the consultations was to gain the perspectives of policymakers and key stakeholders on what should constitute the focus of the study especially in considering international student related issues, and their relationship to current and future policy. The keypersons were from the Ministry of Higher Education (MOHE) and the Education Malaysia Global Services (EMGS). EMGS, is a subsidiary holding company of MOHE, is responsible for screening and processing all international students' applications for immigration related matter. In addition, the consultations sought to identify pertinent policy documents, relevant reports or government publications which should be included in the study. This stage also helped the researcher to identify individuals and/or bodies and institutions which would be able to provide further information as well as key figures in the field of internationalization of higher education inside and outside Malaysia. The consultations set the stage for data collection and analysis. 


\section{Data Collection and Analysis}

Data were collected through semi-structured in-depth interviews conducted in various locations in North Cyprus, Jordan, Bahrain, and United Arab Emirates. The researcher traveled to North Cyprus and the Middle East and spent an extended period of eight months to be familiar and acquainted with the participants in their new environment. Such immersion of self in the research setting is crucial to discover and critically analyze the possible significance of the research setting and to have an emic perspective of the participants themselves. An emic perspective is the insider's view of reality, one of the principal concepts guiding qualitative research and fundamental to understanding how people perceive the world around them (Given, 2008). To do so, researchers need to spend time with research participants and examine their lived experiences in a critical, interpretive framework in order to discover and analyze the possible significance of the higher education environment and process that had led to international students' decision to depart from Malaysia higher education scene. Data from interview transcripts were analysed thematically using the NVivo software which helped researcher in organizing the massive data collections particularly when coding and categorizing activities to develop the emerging themes, and therefore answered the research questions. A presentation session with research colleagues was held to check the validity of the process. Finally, references from the literature were used as evidence to validate the findings.

\section{Sampling of Research Participants}

Twenty-four interviews were conducted with former international students who were registered with several higher institutions in Malaysia from 2010 to 2017 but dropped out due to various issues and continued their study with universities in North Cyprus. Participants were selected purposefully, based on their fit to the study criteria, and snow-balling technique was used in engaging them into the research project. Participants were articulate enough to explain their experiences and perceptions and were willing to be contacted at any time until the times of this report was written. While scholars of qualitative research differ in their opinion about sample size and argued that there is no right answer to the question of the sample size, recent literature shows reaching saturation point is one of most appropriate benchmark in sample size (Boddy, 2016; Morse, 2015; Moser \& Korstjens, 2018; Sim, Saunders, Waterfield, \& Kingstone, 2018). Morse explained saturation is when the characteristics drawn from research questions and within categories emerge as significant in the process of analysis. While Morse (2000) suggests for 6 to 10 participants for phenomenological studies, Creswell (2014); Darwish \& Abdeldayem (2019) said that he found phenomenological studies sample size typically ranged from three to ten participants, while others believe that 10 or fewer participants are sufficient in reaching saturation (Moser \& Korstjens, 2018; Rudestam \& Newton, 2015). However, Smith \& Osborn (2008) proposed that three participants are adequate for first time phenomenological research students.

\section{In-depth Interviews}

In-depth interviews were conducted to elicit descriptions of the participants' experience, perceptions, thoughts, and feelings of being international students, rather than mere description of events. Participants' descriptions and meaning they made of the experience which led to the abandonment of higher education pursuits in Malaysia, were the focus of data analysis. To capture that perception and awareness, the researcher developed a list of 
open-ended questions before each interview to ensure interviews flow within the experience under investigation.

The face-to-face interviews with the participants also allowed for the collection of both verbal and nonverbal information which might not be noticed in an online interview, questionnaire, and online survey. Before each interview session, the participant was briefly explained about the research purpose and was given a consent form to be completed and signed. Participants were also reminded that they could withdraw from the interview at any time or choose not to respond to any of the interview questions. The time duration for these interviews ranged between one and a half hours to four hours or more and they were audio-recorded where the participants consented. When an audio recording was not consented, extensive notes were taken to record both verbal and non-verbal information. Reasons for the decline were feeling self-conscious and uneasiness at being taped recorded. Researcher checked each page of the interview transcript and details which was not clear during the interview would be reconfirmed with participant at the end of each interview session. Brief notes were also taken for audio recorded interviews to ensure accuracy and avoid the possible risk of technical problems with the audio recordings during the transcribing process. It was also to record nonverbal body language as well as to ensure consistency with interview protocol. Participants received a little token of appreciation at the end of the main interview session completed. Recordings of the interviews were transcribed by the researcher herself and the transcripts were checked by the participants in subsequent meetings for accuracy and inter-rating purposes. When subsequent face to face meeting was not possible, the transcripts were sent via email to the participants, and discussion on feedbacks or comments was carried out through audio or video calls.

\section{Discussion and Conclusion}

The focus of this study was to examine the lived experiences of international student dropouts and how the experiences influenced their decision to leave from Malaysia higher education system. Furthermore, the study was also interested in understanding the impact of the narratives they shared with others especially those who plan to study in Malaysian higher institutions. Description of experiences in the higher education setting and those related to community relationships provided the context of the experience. When these experiences and perceptions were put together, they provided a holistic understanding of the participants' experience of early withdrawal from Malaysian higher education system. The dynamic process of international student early withdrawal required more than one negative incident. Apart from contributing to the existing body of literature, this study is important in supporting Malaysian government's higher education national policy in finding strategies to cope with the international student withdrawals phenomenon and enhance existing policy, particularly on international student management framework. Furthermore, its findings can promote the exchange of ideas, initiatives and experiences related to this phenomenon and may suggest to higher institutions, educational leaders and policymakers for effective interventions to support internationalization of higher education in Malaysia education system, aligned with national goal and aspiration.

\section{Limitations}

There are two limitations of the study. Firstly, this was a study of international students' lived experiences. It was not a study of institutions, programs, curricula, or academic disciplines. The in-depth nature of the study and the small number of participants necessarily limited the 
degree to which the findings might be transferable to international students who dropped out. Secondly, the research approached data collection from an individual perspective rather than a systemic or societal perspective and therefore the findings reflect individual participants' descriptions of their lived experiences and therefore carry all the limitations of any self-reported data.

However, although the findings are based on the perspectives of a small subgroup of Middle eastern origin students, this study laid the groundwork for a more extensive investigation of international student withdrawal, part of student mobility related research area.

\section{Theoretical Contributions of the Study}

While other studies isolated and decontextualized selected factors in their attempts to quantify student's experiences, this study employed a naturalistic approach, phenomenological enquiry that was sensitive to the participant's experience. Furthermore, most existing available studies on international student withdrawal are from the perspective of information system and computer field. While the approach used was the utilization of meta data set to provide insight into international student dropout phenomenon and to predict their risk of dropping out, the present study, a humanistic approach of phenomenological enquiry was used, describing the phenomenon from the lens of the dropouts. As such, the approach used in this study contributes depth to the existing body of research devoted to the understanding of the phenomenon of international student withdrawals from higher education pursuits. Furthermore, the approach adopted in the study, provide an avenue for the least heard voices, international students drop-out to be heard.

\section{References}

Abdullah, A. (2013). Malaysian higher education and the United States as a model: Policy borrowing or policy learning? [Doctoral dissertation, University of Melbourne, Australia].

Abdullah, D., Abd Aziz, M. I., \& Ibrahim, M. A. L. (2014). A "research" into international student-related research: (Re)Visualising our stand? Higher Education, 67(3), 235-253. https://doi.org/10.1007/s10734-013-9647-3

Adams, J. L., \& Becker, W. E. (1990). Course withdrawals: A probit model and policy recommendations. Research in Higher Education, 31(6), 519-538. https://doi.org/10.1007/BF00992619

Aina, C., Casalone, G., Baici, E., \& Pastore, F. (2018). The economics of university dropouts and delayed graduation: A survey. IZA - Institute of Labor Economics, Germany.

Akiba, H. (2008). The changing face of transnational education in Malaysia: A case study of international offshore university programs. [Doctoral dissertation, University of Minnesota]. Faculty of the Graduate School.

Ashour, S. (2019). Analysis of the attrition phenomenon through the lens of university dropouts in the United Arab Emirates. Journal of Applied Research in Higher Education. https://doi.org/10.1108/jarhe-05-2019-0110

Astin, A. W. (1984). Student involvement: A development theory for higher education. Journal of College Student Development, 25, 297-308.

Australian Government. (2015). International student survey 2014 - Overview report. Retrieved from https://internationaleducation.gov.au/research/researchpapers/Documents/ISS 2014 Report Final.pdf 
Barney, K. (2016). Listening to and learning from the experiences of Aboriginal and Torres Strait Islander students to facilitate success. Student Success, 7(71), 1-11. https://doi.org/10.5204/ssj.v7i1.317

Bean, J. P., \& Metzner, B. S. (1985). A conceptual model of nontraditional undergraduate student attrition. Research in Higher Education, 55, 485-540.

Boddy, C. R. (2016). Sample size for qualitative research. Qualitative Market Research: An International Journal, 19(4), 426-432. Retrieved from

http://dx.doi.org/10.1108/13522750710819720

Burke, A. (2019). Student retention models in higher education - A literature review. Retrieved February 4, 2019, from https://www.aacrao.org/research-publications/quarterlyjournals/college-university-journal/issue/c-u-vol.-94-no.-2-spring

Cabrera, L., Tomas, J., Alvarez, P., \& Gonzalez, M. (2006). The problem of university dropout. RELIEVE, 12(2), 171-202. Retrieved from http://www.uv.es/RELIEVE/v12n2/RELIEVEv12n2_1.htm?iframe=true\&width $=80 \% 25 \&$ height $=80 \% 25$

Creswell, J. W. (2014). Research design: Qualitative, quantitative, and mixed methods approaches. Sage Publications, Inc. (4th ed.). Sage Publications, Inc.

Creswell, J. W., \& Poth, C. N. (2018). Qualitative inquiry and research design - Choosing among five approaches (Fourth). SAGE.

Cummings, A. M. (2014). The impact of student support services on academic success at a select historically black college and university. [Doctoral dissertation, University of North Florida. Retrieved from http://digitalcommons.unf.edu/etd/532

Darwish, S., \& Abdeldayem, M. M. (2019). Risk Management and Business Ethics: Relations and Impacts in the GCC. International Journal of Civil Engineering and Technology, 10(10), 489-504.

De Wit, H. (2008). The dynamics of international student circulation in a global context. In Australian International Education Conference (pp. 1-10).

DeMonbrun, R. M., Brown, M., \& Teasley, S. D. (2019). Enrollment patterns and students' risk of academic difficulty. Journal of Applied Research in Higher Education, 12(1), 97-108. https://doi.org/10.1108/JARHE-11-2018-0252

Dessoff, A. (2012). Asia's burgeoning higher education hubs. International Educator, (JulyAugust), 16-26.

Ergin, H., de Wit, H., \& Leask, B. (2019). Forced internationalization of higher education: An emerging phenomenon. International Higher Education, (97), 9-10.

Ethington, C. A. (1990). A psychological model of student persistence. Research in Higher Education, 31(3), 279-293. https://doi.org/10.1007/BF00992313

Geisinger, B. N., \& Raman, D. R. (2013). Why they leave: Understanding student attrition from engineering majors. International Journal of Engineering Education, 29(4), 914-925. Retrieved from

http://lib.dr.iastate.edu/abe_eng_pubs\%0Ahttp://lib.dr.iastate.edu/\%0Ahttp://lib.dr.i astate.edu/abe_eng_pubs/607

Gitto, L., Minervini, L. F., \& Monaco, L. (2016). University dropouts in Italy: Are supply side characteristics part of the problem? Economic Analysis and Policy, 49, 108-116. https://doi.org/10.1016/j.eap.2015.12.004

Given, L. M. (2008). The SAGE encyclopedia of qualitative research methods - Volumes 1 \& 2. (L. M. Given \& K. Saumure, Eds.), SAGE Reference Publication. Sage Publications, Inc.

Hilaluddin, T. (2013). Exploring constraints on and support for quality teaching at a higher 
education institution in Malaysia. Doctoral dissertation, Massey University.

Huo, H., Cui, J., Hein, S., Padgett, Z., Ossolinski, M., Raim, R., \& Zhang, J. (2020). Predicting dropout for nontraditional undergraduate students: A machine learning approach. Journal of College Student Retention: Research, Theory \& Practice, 0(0), 1-24. https://doi.org/10.1177/1521025120963821

Kehm, B. M., Larsen, M. R., \& Sommersel, H. B. (2019). Student dropout from universities in Europe: A review of empirical literature. Hungarian Educational Research Journal, 9(2), 147-164. https://doi.org/10.1556/063.9.2019.1.18

Kercher, J. (2018). Academic success and dropout among international students in Germany and other major host countries. DAAD Focus, (July), 1-23.

Lassibille, G., \& Gomez, L. N. (2008). Why do higher education students drop out? Evidence from Spain. Education Economics, 16(1), 89-105.

https://doi.org/10.1080/09645290701523267

Martirosyan, N. M., Bustamante, R., \& Saxon, D. P. (2019). Academic and social support services for international students: Current practices. Journal of International Students, 9(1), 172-191. https://doi.org/10.32674/jis.v9i1.275

Mazzarol, T., \& Soutar, G. N. (2002). "Push-pull" factors influencing international student destination choice. International Journal of Educational Management, 16(2), 82-90.

Mitchell, F. T. (1942). Why freshmen leave college. The Journal of Higher Education, 13(2), 95-100. https://doi.org/10.1080/00221546.1942.11773255

MoHE. (2015). Malaysia education blueprint 2015-2025 (Higher education). MoHE. https://doi.org/10.5923/j.ijis.20120206.05

MoHE. (2017). Department of Higher Education Strategic Plan 2018 - 2022 (Vol. 2025).

MoHE. (2018). Amanat menteri pendidikan tinggi [Speech of the minister of higher education]. MoHE, 1-25.

Morse, J. M. (2000). Determining sample size. Qualitative Health Research, 10(1), 3-5.

Morse, J. M. (2015). Data were saturated... Qualitative Health Research, 25(5), 587-588. https://doi.org/10.1177/1049732315576699

Moser, A., \& Korstjens, I. (2018). Series: Practical guidance to qualitative research. Part 3: Sampling, data collection and analysis. European Journal of General Practice, 24(1), 918. https://doi.org/10.1080/13814788.2017.1375091

Moustakas, C. (1994). Phenomenological research methods. Sage Publications. SAGE Publications Inc.

Outhred, T., \& Chester, A. (2013). Improving the international student experience in Australia through embedded peer mentoring. Mentoring \& Tutoring: Partnership in Learning, 21(3), 312-332. https://doi.org/10.1080/13611267.2013.851499

Owens, J. (2009). Student withdrawal from higher education (No. 042/2009). Department for Children, Education, Lifelong Learning and Skills. Welsh Assembly of Government.

Perez-Encinas, A., \& Rodriguez-Pomeda, J. (2018). International students' perceptions of their needs when going abroad: Services on demand. Journal of Studies in International Education, 22(1), 20-36. https://doi.org/10.1177/1028315317724556

Perring, G. (2014). Best practice in international student experience. In Internationalisation of Higher Education Seminar.

Rovira, S., Puertas, E., \& Igual, L. (2017). Data-driven system to predict academic grades and dropout. PLOS ONE, 12(2), 1-21. https://doi.org/10.1371/journal.pone.0171207

Rudestam, K. E., \& Newton, R. R. (2015). Surviving your dissertation: A comprehensive guide to content and process (Fourth). SAGE Publishing. Retrieved from 
http://books.google.com/books?id=vmWdAAAAMAAJ\&pgis=1

Sangodiah, A., Beleya, P., Muniandy, M., Heng, L. E., \& SPR, C. R. (2015). Minimizing student attrition in higher learning institutions in Malaysia using support vector machine. Journal of Theoretical and Applied Information Technology, 71(3), 377-385.

Sim, J., Saunders, B., Waterfield, J., \& Kingstone, T. (2018). Can sample size in qualitative research be determined a priori? International Journal of Social Research Methodology, 21(5), 619-634. https://doi.org/10.1080/13645579.2018.1454643

Smith, J. A., Larkin, M., \& Flowers, P. (2009). Interpretative phenomenological analysis: Theory, method and research. SAGE Publications Ltd. SAGE Publications Ltd. https://doi.org/10.1002/9780470776278.ch10

Spady, W. G. (1970). Dropouts from higher education: an interdisciplinary review and synthesis. Interchange, 1(1), 64-85.

https://doi.org/https://doi.org/10.1007/BF02214313

Stephenson, A. L., Heckert, D. A., \& Yerger, D. B. (2020). Examining college student retention: a closer look at low self-control. International Journal of Educational Management, 34(5), 953-964. https://doi.org/10.1108/IJEM-07-2018-0208

Tarmizi, S. S. A., Mutalib, S., Hamid, N. H. A., \& Rahman, S. A. (2019). A review on student attrition in higher education using big data analytics and data mining techniques. I.J. Modern Education and Computer Science, 8, 1-14. https://doi.org/10.5815/ijmecs.2019.08.01

Tinto, V. (1975). Dropout from higher education: A theoretical synthesis of recent research. Review of Educational Research, 45(1), 89-125. Retrieved from http://www.jstor.org/stable/pdf/1170024.pdf

Tinto, V. (1987). A theory of individual departure from institutions of higher education, 84137. Retrieved from

http://scholar.google.com/scholar?hl=en\&btnG=Search\&q=intitle:A+Theory+of+Indivi dual+Departure+from+Institutions+of+Higher+Education\#8

Tinto, V. (1988). Stages of student departure. The Journal of Higher Education, 59(4), 438455.

Tinto, V. (1993). Leaving college: Rethinking the causes and cures of student attrition. Chicago: University of Chicago Press.

Tinto, V. (1997). Classrooms as communities. The Journal of Higher Education, 68(6), 599-623. https://doi.org/10.4324/9781351263443-10

Von Hippel, P. T., \& Hofflinger, A. (2020). The data revolution comes to higher education: identifying students at risk of dropout in Chile. Journal of Higher Education Policy and Management, 1-22. https://doi.org/10.1080/1360080X.2020.1739800

Willcoxson, L., Cotter, J., \& Joy, S. (2011). Beyond the first-year experience: the impact on attrition of student experiences throughout undergraduate degree studies in six diverse universities. Studies in Higher Education, 36(3), 331-352. 